\title{
New Cavernicolous Millipeds of the Family Cambalidae (Cambalidea: Spirostreptida) from Texas (U.S.A.) and Mexico
}

\author{
By Nell B. Causey ${ }^{1}$ ) \\ With plates $57(1)-58(2)$
}

Millipeds of the genus Cambala are abundant in Texas caves. In three widely separated cave areas, there are two allopatric species, of which one is represented by two subspecies. Cambala speobia (Chamberlin), a troglobite, surely will also be found in Coahuila. Of the two subspecies of $C$.reddelli n. sp., the nominate subspecies is a troglophile that also occurs in epigean sites in New Mexico, and inornatus is probably a troglobite. The last is of special interest because of the very weak development of the dorsal crests and pore crests. Mexicambala russelli, n. gen. and sp., a troglobite from San Luis Potosi, is more highly modified by cave life than any other cambalid. These are the only cambalids that are known from the caves of western North America and Mexico.

In the states east of Texas, Cambala minor (Bollman) and occasionally other congeners are collected in the entrance and twilight zone of caves. Cambala loomisi (Hoffman) occurs in a cave in south-central Alabama.

Most of the specimens that were studied in the preparation of this paper were collected by the biological division of the Texas Speleological Survey, of which Mr. James Reddell is editor. The remaining specimens were collected by Dr. Richard O. Albert, Mr. James K. Baker, Dr. T. C. Barr, Jr., and Dr. C. C. Hoff. I am grateful to all of these collectors.

The deposition is mentioned in the section on each species.

\section{Genus Cambala Gray}

Cambala Gray, 1832, Insecta, in Griffith, The animal kingdom... by Baron Cuvier, 15, pl. 135. Loomis, 1938, Proc. U.S. Nat. Mus., $86: 37$. Chamberlin and Hofman, 1958, U.S. Nat. Mus. Bull. 212:173. (Type species: Julus annulatus Say, by monotypy.)

Eclytus Chamberlin, (not Holmgren 1855) Chamberlin, 1952, Ent. News, 63:10. (Type species: E. speobius Chamberlin, by monotypy and original designation.)

Eclomus Chamberlin, 1952, Ent. News, 63:71. New Synonomy.

1) Department of Zoology and Physiology, Louisiana State University, Baton Rouge, Louisiana, U.S.A. 
This genus was summarized by Loomis in 1938. A needed revision is contemplated by Hoffman (1958) to bring together the species that have been described since then.

Cambala differs from Mexicambala chiefly in the longer, slightly salient ventral margins of the collum, the fewer setae on the anal valves, and the bilobed coxite of the anterior gonopods. The species of Cambala differ chiefly in body size, number of ocelli, amount of body pigment, prominence of dorsal crests and pore crests, segment on which crests begin, size and distribution of lobes on legs of mature males, presence or absence of tarsal claw of legpair 1 of males, and details of both pairs of gonopods. Dorsal crests begin on segments 2, 3 , or 4 . Pores begin on segment 5 . A troglobite, C. speobia, lacks ocelli; all other species have several ocelli in 1 or 2 series. Two setae are on the mesial margin of each anal valve.

Article 2 of legpair 1 of males is about twice the width of article 3 . One or 2 articles of 2 or more pairs of legs of mature males are enlarged. The articles that are modified are 4 and 5, or only article 4, of the following legpairs: 6 and 7, 4 through 7, and the first 24 or so postgonopodal legs.

Sternum of anterior gonopods is somewhat rectangular and longer than it is wide. Distal margin of coxite is bilobed; anterior lobe bears macrosetae; flagellum is long. Telopodite is setose on distal surface; distal margin is divided into two shallow lobes.

Anterior process of coxa of posterior gonopods is either simple or bilobed; it bears curved macrosetae. Ectal process of coxa is smaller than anterior process and either simple or divided. A vertical series of minute spurs is on mesial surface of coxa. Telopodite bears short, thick spurs on apex. I am uncertain whether the telopodite always consists of 2 articles; possibly the number is not constant.

Distribution. The United States from western Washington and nothern Idaho to the Atlantic Coast. Most abundant in the Appalachian Mountains.

Species. The number is uncertain. Of the 10 that were listed by Chamberlin and Hoffman (1958), some are probably synonyms or subspecies of C.minor. Epigean, troglophilic, and troglobitic species are included.

\section{KEY TO THE SPECIES OF CAMBALA IN TEXAS GAVES}

1. Without ocelli. Maximum body width $1.9 \mathrm{~mm}$. Central and

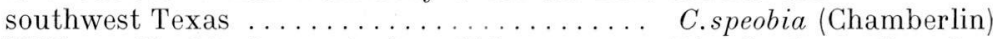
With ocelli. Maximum body width $1.2 \mathrm{~mm}$. Distribution otherwise.

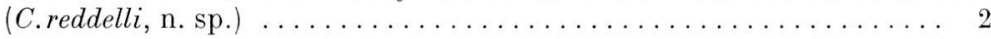


2. With distinct dorsal crests and pore crests. Ocelli usually in 2 series.

West Texas .................... C.reddelli reddelli, n. subsp.

Lacking distinct dorsal crests and pore crests. Ocelli in 1 series.

Northwest Texas .................. C.r.inornatus, n.subsp.

The presence of a tarsal claw on legpair 1 of the male distinguishes the species of Cambala that are treated in this paper from the more eastern congeners, including those in east Texas.

\section{$C A M B A L A R E D D E L L I$, new species}

Diagnosis. A polytypic species near C.washingtonensis Causey in the form of the gonopods; differs in the smaller body size, fewer segments, the smaller lobes on the pregonopodal legs, and the absence of lobes on the postgonopodal legs. Characterized especially by a pair of setae on the apex of the caudal tergite.

Length 16 to $24 \mathrm{~mm}$. Width 0.9 to $1.2 \mathrm{~mm}$. 41 to 56 segments. From 9 to 2 ocelli are arranged in either 1 or 2 irregular rows.

Distribution. Caves and epigean sites in west and northwest Texas and New Mexico. It possibly occurs also in Colorado.

Subspecies. Two subspecies are described here. They differ in the prominence of the crests and in the number of ocelli. An epigean collection from northern New Mexico is intermediate between them.

This species is named for Mr. James L. Reddell in recognition of his outstanding collections of troglobitic millipeds from Texas and Mexico.

\section{Cambala reddelli reddelli, new subspecies}

Figures 1-4

Diagnosis. A small-bodied troglophile that is like $C$. r. inornatus in the form of the gonopods and lobation of the legs; differs in the greater development of the dorsal crests and pore crests and the arrangement of the ocelli in 2 irregular series.

Male holotype. Length $16 \mathrm{~mm}$. Width $0.9 \mathrm{~mm}$. 40 segments, of which the last 2 are legless. Flesh-colored and with red lateral glands when freshly preserved; became red-brown in alcohol. Head is as in congeners. Antennae reach back to margin of segment 3 ; ratio of length of articles 1 through 7 and width of articles 5 and 6 (in parentheses) is: $19: 26: 30: 21: 23(22): 25(20): 4$. Ocelli, which are partly covered by collum, are in rows of about 3,5 .

Body is not markedly narrowed behind head or swollen at segment 7. Collum (fig. 1) is a little longer than segments 2 and 3 , the anteroventral margin is lifted slightly to allow the antenna to be carried between it and mandible, but caudo-ventral angle is not lifted. Dorsal 
surface of first 3 and last 2 segments is entirely smooth. Six weak crests are on segment 4 and the third and fourth segments preceding the last. Dorsal crests of typical body segments are a little less prominent than in $C$.xashingtonensis Causey and much less prominent than in C.speobia (Chamberlin); pore crests have the usual pear shape, but are flattened and no more prominent than the 4 dorsal crests; surface between crests is smooth; below the pore crests there are about 16 horizontal striae, of which the upper are the most prominent. Horizontal striae on the first 3 segments are indistinct. Horizontal striae are distinct on lateral and ventral surfaces and along segmental sulcus of dorsal surface of prozonites. Caudal tergite is a little shorter than anal valves; caudal margin is rounded; there is a pair of setae at the apex and another pair at the intersections with the anal scale. Two pairs of setae are on mesial margins of anal valves, and 1 pair is on anal scale. Caudal margin of anal scale is weakly convex.

Legpair 1 consists of 6 articles and a terminal claw; as in the congeners, article 2 is about twice as wide as article 3 . Articles 4 and 5 of legpairs 6 (fig. 2) and 7 are moderately enlarged for the genus. No postgonopodal legs are enlarged.

Figure 3 is an anterior view of the anterior gonopods, and figure 4 is an ectal view of the right posterior gonopod of a paratype. There is very little difference between the gonopods of C.reddelli and C.washingtonensis. The latter differs in the larger body size and in the lobation of article 5 (fig. 6) of the first 24 or so legpairs immediately behind the gonopods.

Female paratype. Length $19 \mathrm{~mm}$. Width $1.0 \mathrm{~mm}$. 46 segments, of which the last 2 are legless.

Variations. Summary of 9 specimens: Length 16 to $20 \mathrm{~mm}$. Width 0.9 to $1.1 \mathrm{~mm} .41$ to 49 segments, of which 2 or 3 are legless. Ocelli are unequal in size; there are from 7 to 11 in 2 irregular rows that are partly covered by the collum.

Distribution. Cavernicolous and epigean in west Texas and New Mexico.

Type locality and specimens. Texas. Culbertson Co.: Border

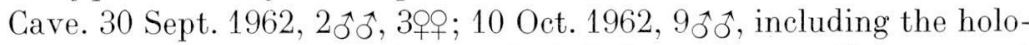
type, 2490, immature specimens; J. K. Baker, collector. Holotype and paratype of both sexes are in the American Mus. Nat. Hist. (New York). Remaining paratypes of both sexes are in the U.S. Nat. Mus. and author's collection.

Other record. New Mexico. San Miguel Co.: west of Cowles, end of road to Lake Catherina, sifting in oak litter, 8,400 ft. alt., 26 Aug.

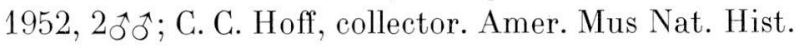


This milliped has not appeared in any of the several collections that I have from the caves of Eddy County, New Mexico.

Record of population intermediate between C.r.reddelli and C.r. inornatus: New Mexico. Colfax Co: Philmont Scout Ranch, Porcupine Trail, 9,600 ft. alt., about 15 miles southwest of Cimmaron, Aug. 12 to 28 Aug. 1962, many specimens; R. C. Albert, collector. Amer. Mus. Nat. Hist. and author's collection. Summary of 4 specimens: Length 20 to $24 \mathrm{~mm}$. Width 1.0 to $1.2 \mathrm{~mm} .51$ to 56 segments. Ocelli are unequal in size and arranged in 2 (or rarely 1) uneven rows of 7-2, 7-1, 6-1, 7-0. Dorsal crests and pore crests are low, wide, and much nearer the condition in inornatus than in the nominate subspecies. Horizontal striae are well developed, as in the nominate subspecies. Lobes on legpairs 6 and 7 are a little larger than in other populations.

\section{Cambala reddelli inornatus, new subspecies}

\section{Figure 5}

Nannolene sp. Causey in Reddell and Russell, 1963, Texas Spel. Surv. 1 (8): 3 .

Diagnosis. A small-bodied cavernicole that is like C.r.reddelli in the form of the gonopods and lobation of the legs; differs from it and all other congeners in the presence of only very slight traces of dorsal crests and pore crests; also differs from the nominate subspecies in that the ocelli, of which there are from 2 to 7, are arranged in a single series.

Male holot ype. Length about $21 \mathrm{~mm}$. Width $1.0 \mathrm{~mm}$. 51 segments, of which the last 2 are legless. Ocelli are small, round, and contiguous; 3 are on one side and 2 on other side. Pores begin on segment 5; slight traces of large, circular pore crests remain. Below the pores, metazonites and posterior half of prozonites are horizontally striated; across the dorsum, prozonites lack striae and a series of pits is in segmental sulcus. Figure 5 is a lateral view of a typical body segment. If the segments are viewed from behind, slight traces of 4 dorsal crests and the upper horizontal striae can be seen.

Gonopods and characters that are not mentioned are as in the nominate subspecies.

Variations. Length 18 to $24 \mathrm{~mm}$. Width 0.9 to $1.0 \mathrm{~mm}$. 44 to 55 segments. 2 to 7 ocelli are in one row; some may be covered by the collum.

The two populations in the caves in Childress and Wheeler Counties differ in body proportions, number of segments, and number of ocelli. Specimens from Big Mouth Cave and Small Mouth Caves (Wheeler County) are about 24 times as long as wide, have from 51 to 54 body 
segments, and 2 to 4 round ocelli. Specimens from Windmill Crack Cave (Childress County) are about 20 times as long as wide, have from 44 to 51 body segments, and 3 to 7 ocelli.

Ecology. The records suggest that C.r.inornatus is an obligate cavernicole. The reduced number of ocelli is the only morphological evidence of modification by cave life. The loss of the crests may have occurred before the cave habitat was adopted. The ecological evidence, as reported by one of the collectors, Mr. James R. Reddell, suggests that inornatus is a troglobite. He wrote (letter to author 22 May 1963): "We recently investigated about 40 gypsum caves in Northwest Texas. Most of the caves examined are quite recent in origin, despite their large volume, and most are subject to violent and complete flooding. I found almost no indications of troglobites in the caves, Big and Small Mouths in Wheeler County and Bateman Cave in King County being the only notable exceptions. In these large caves and Windmill Crack I found the only small, pale spiders... The area is definitely not a good collecting area." Later (letter 12 June 1963 to author) he added: "I have thought at length about the question of its being troglobitic, and would be tempted to say that it is. The only active forms that we saw were in total darkness. Intensive searching in daylight at the entrance to Small Mouth Cave, where it was quite moist and food was abundant, yielded no animals. The same held true at Big Mouth Cave, where the most moist part of the cave was in subdued daylight. The only animals found, however, in that cave were in a very dim twilight, under rocks, and quite inactive. Another matter of interest is that since the discovery of Pleistocene fossils, the caves appear to be older than we had postulated at first, at least some of them. What is apparently a troglobitic isopod was also found in another cave. None of these are conclusive, but I do think that they suggest that [inornatus] is a troglobite."

Distribution. Caves in northwest Texas.

Type locality and specimens. Texas. Wheeler Co.: Big Mouth Cave, 2 miles north of Shamrock, 19 Oct., 1957, ㅇ, T.C.Barr, Jr.;

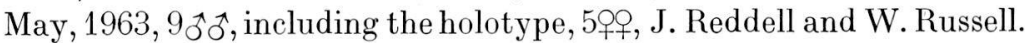
Small Mouth Cave, 100 yards east of Big Mouth Cave, May, 1963, o, Reddell and Russell. Holotypes and paratypes of both sexes are in the American Mus. Nat. Hist. (New York); remaining specimens are in the author's collection.

Other record. Childress Co.: Windmill Crack, 20 miles north of Childress, May, 1963, $9 \widehat{\jmath} \widehat{\jmath}, 1290$, Reddell and Russell. Amer. Mus. Nat. Hist. and author's collection. 


\section{CAMBALA SPEOBIA (Chamberlin), new combination}

Eclytus (not Holmgren 1855) speobius Chamberlin, 1952, Ent. News 63:10. Eclomus speobius, Chamberlin, 1952, Ent. News 63:71. Chamberlin and Hoffman, 1958, U.S. Nat. Mus. Bull. 212:175.

Cambala caeca Loomis, 1953, Jour. Washington Acad. Sci., 43 (10): 43 (12): 417, figs. 1-3. New Synonomy.

Cambala captiosa Causey, 1959, Proc. Biol. Soc. Washington, 72:69-71, figs. 1-3. New Synonomy.

Nomenclatorial note. I have examined the many collections of millipeds made by the Texas Speleological Survey and am convinced that only one cambaloid species has been collected in the caves of central and southwest Texas. The members of the Survey made large, careful collections in Wyatt Cave (the type locality of E.speobius and C.caeca) and nearby caves in a special effort to determine whether there are two cambaloid species there. They found only one, confirming Loomis' (1953) conjecture that serious errors were introduced into the original description of Eclomus speobius and that Cambala caeca is a synonym of E.speobius.

Diagnosis. A medium-sized troglobite that is related to the eastern congeners in the form of the anterior gonopods. Distinguished from them by the absence of ocelli and by the presence of a tarsal claw on legpair 1 of the male.

Maximum width and length are 1.9 and $33 \mathrm{~mm}$., respectively. 37 to 50 segments, of which the last 1 to 3 are legless. Body is flesh-colored and pore glands are red in life; turns dark red-brown in alcohol. With no conspicuous cave modifications other than absence of ocelli; an occasional immature specimen has 1 or 2 ocelli. In the mature male, large, rounded lobe is on the ventral surface of article 4 of legpairs 6 and 7 , and article 5 of the same legs is swollen. Dorsal crests are slightly indicated on segment 3 ; on segment 4 there are 6 subequal slender crests which are slightly lower than crests on typical segments; pore crests and pores begin on segment 5. Crests are narrower and higher than in C.r.reddelli. Apex of caudal tergite is unusually thick for the genus, rounded, a little longer than anal valves, and asetose.

The following corrections should be made to the figure of the posterior gonopod, as drawn by Causey (1959): the telopodite consists of 2 articles, with the length of the longer terminal article approximately twice as great as the width; the posterior coxite is bilobed, with the mesial lobe flattened and asetose; a vertical series of minute, curved spurs is on the mesial surface of the coxa.

Ecology. Found on moist guano, silt, and walls and under organic debris and rocks in caves from the twilight zone back several hundred 
feet in total darkness. Frequently is collected with members of the polydesmoid genus Speodesmus.

Distribution. Caves in the following central and southwest Texas counties: Bandera, Bell, Bexar, Burnet, Comal, Coryell, Edwards, Hays, Irion, Kendall, Kinney, Lampasas, Medina, Menard, Real, San Saba, Sutton, Terrell, Travis, Uvalde, Val Verde, and Williamson.

Type locality and specimens. Eclomus speobius Chamberlin. Texas. Edwards (not Sutton) Co.: Wyatt Cave. Many cotypes and paratypes (Felton Cave) are in the Chamberlin Collection. I have not examined them. Topotypes, including 69 mature and immature specimens collected by James Reddell and Bill McKenzie 21 Sept. 1963, have been divided among the U.S. Nat. Mus., Amer. Mus. Nat. Hist. and the author's collection.

Cambala caeca Loomis. Texas. Edwards Co.: Wyatt Cave, ơ holotype, U.S. Nat. Mus., no. 2087. Felton Cave, 1290 paratypes.

Cambala captiosa Causey. Texas. Williamson Co.: Beck's Ranch Cave,

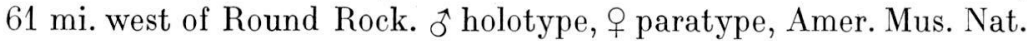
Hist. Paratypes and many topotypes are in the author's collection.

\section{Genus Mexicambala, new}

Type species. Mexicambala russelli, new species. Monobasic.

Diagnosis. Near Cambala; differs in that the sides of the collum are shorter and closer to the head, the setae on the anal valves and anal scale are numerous, and the distal margin of the coxite of the anterior gonopods is not divided.

\section{MEXICAMBALA RUSSELLI, new species} Figures $7-13$

Diagnosis. A depigmented, eyeless troglobite that is characterized by 4 conspicuous, serrated dorsal crests, prominent pore crests, and elongated tarsal claws and antennae.

Male holotype. Length $21 \mathrm{~mm}$. Width $1.3 \mathrm{~mm}$. 39 segments, of which the last 2 are legless. Flesh-colored except for the darker pore crests when freshly preserved; later became medium gray in alcohol.

Head resembles species of Cambala. 16 labral setae. 4 widely separated clypeal setae. Antennae reach back to margin of segment 4 ; ratio of length of articles 1 through 7 and width of articles 5 and 6 (in parentheses) is: $30: 40: 57: 46: 45(29): 51(30) 10$; the usual sensory areas are on segments 5 and $6 ; 4$ terminal cones.

Body is slightly narrowed behind head. Segment 7 is not swollen. Prozonites are markedly narrower than metazonites. Collum (fig. 7) is length of segments 2 and 3; its lateral margin is short and close 
to the head, and the thin margin of the head capsule fits into a shallow emargination. Dorsal surface of collum is smooth. Segments 2 and 3 have slight traces of dorsal crests and distinct but uneven horizontal striae. 4 dorsal crests, lacking serrations, are on segment 4. By segment 9 dorsal crests reach their maximum size and typical shape (fig. 8); they are thin, high, and divided into 3 angular or rounded serrations. Pores and pore crests begin on segment 5; distal two-thirds of each pore crest is thin and sharp, resembling the dorsal crests; anterior one-third of pore crest is high, rounded in front and angular behind; pore opens on flat outer surface of crest. Crests are lower on 2 segments preceding the last. Last segment lacks crests and lateral striae. Surface between crests is smooth and shining. Below crests there is one weak horizontal crest and a double series of uneven rectangular areas that are continuous with the single series of rectangular areas on posterior half of prozonite; anterior half of prozonite is minutely honeycombed. Caudal tergite is a little longer than penult segment; caudal margin is rounded, entirely covering anal valves from above. Distal margin of anal scale is straight. Anal valves are not margined. Setae are scattered over anal valves and anal scale; anal tergite is asetose (fig. 9).

Legpair 1 (fig. 10) consists of 6 articles and a claw; article 2 is a little wider than article 3 , but not as wide as in species of Cambala. No legs are lobed or swollen. Tarsal claws are about two-thirds the length of the tarsi. Penes are short, contiguous, and 2 macrosetae are on the apex of each one. As in species of Cambala, ventral margins of segment 6 overlap, ventral margins of segment 7 are contiguous, and opening of gonopodal cavity is semicircular.

Gonopods closely resemble species of Cambala. Anterior gonopods differ in that sternum is shorter and distal margin of coxite and telopodite are not divided (fig. 11). Posterior gonopods differ (figs. 12, 13 ) in that the mesial row of nodules is larger and the telopodite does not have a distinct transverse septum.

Note. The holotype may lack a molt of maturity. If so, some of the legs of the male may be found to be enlarged after the final molt.

Female paratype. Length about $25 \mathrm{~mm}$. Width $1.6 \mathrm{~mm} .43 \mathrm{seg}-$ ments, of which the last 2 are legless.

Variations. Mature specimens have from 39 to 43 segments, are 21 to $26 \mathrm{~mm}$. long, and 1.3 to $1.6 \mathrm{~mm}$. wide. Immature specimens are known with 38,36 , and 32 segments.

Distribution. Type locality in eastcentral Mexico.

Type locality and specimens. Mexico. San Luis Potosí. Cueva de la Parra, $5 \mathrm{~km}$. north of Xilitla, in total darkness, 26 Oct. 1963. 
$2 \hat{\jmath} \widehat{0}$, including the holotype, 2 mature $\circ \circ, 4$ immature $\circ \circ$; William H. Russell, collector. Holotype and $q$ paratype are in American Mus. Nat. Hist. (New York). Remaining specimens are in the author's collection.

This species is named for the collector, Mr. William H. Russell.

\section{SUMMARY}

The cavernicoles include: (1) Cambala speobia (Chamberlin), troglobitic in central and southwest Texas; (2) C.reddelli reddelli n. sp. and subsp., troglophilic in west Texas and epigean in New Mexico; (3) C.reddelli inornatus n. subsp., troglobitic in northwest Texas; and (4) Mexicambala russelli n. gen. and sp., troglobitic in southern San Luis Potosi. They are described and figured, and a key is given.

\section{RÉSUMÉ}

Les Diplopodes Cambalides actuellement connus des parties centrale et occidentale du Texas (U.S.A.) et de la partie du Nord-Est du Mexique sont les formes suivantes: $1^{\circ}$ - Cambala speobia (Chamberlin), troglobie du Texas, dans les parties centrale et sud-occidentale; $2^{\circ}$ - C. reddelli reddelli $\mathrm{sp}$. et subsp. nov., troglophile dans le Texas occidental et épigé dans le NouveauMexique; $3^{\circ}$ - C.reddelli inornatus subsp. nov., troglobie dans le Nord-Ouest $\mathrm{du}$ Texas; et $4^{\circ}-$ Mexicambala russelli gen. et sp. nov., troglobie dans le Sud de l'Etat de San Luis Potosi (Mexique). L'auteur donne ici les descriptions et dessins de ces espèces, et un tableau de leur détermination.

\section{R E FERENCES}

Causey, Nell B. - 1959: Two new troglobyric millipeds from Texas. Proc. Biol. Soc. Washington 72:69-76, 6 figs.

Chamberlin, R. V., and Hoffman, R. L.: - 1958 Checklist of the Millipeds of North America. U.S. Nat. Mus. Bull. 212:1-236.

Hoffman, R.L. - 1956: New genera and species of cavernicolous diplopods from Alabama. Geol. Sur. Alabama, Mus. Paper 35, pp. 1-11, 11 figs.

- 1958: Appalachian Cambalidae: Taxonomy and distribution (Diplopoda: Spirostreptida). Jour. Washington Acad. Sci. 48 (3):90-94, 1 map.

Rediell, James L., and Russell, William H. - 1962: The caves of Northwest Texas. Texas Spel. Sur. 1 (8):1-56. Mimeographed.

\section{EXPLANATION OF PLATES 57 (1)-58 (2)}

Figs. 1-4. Cambala r. reddelli, n. subsp., male paratype. 1. Anterior end of body; 2. Sixth leg.; 3. Anterior gonopods, anterior view; 4. Right posterior gonopod, ectal view.

Fig. 5. Cambala r. inornatus, n. subsp. Middle body segment of paratype.

Fig. 6. Cambala washingtonensis Causey, 1954. Leg from segment 8 of male from Albion, Whitman County, Washington.

Figs. 7-13. Mexicambala russelli, n. gen. and sp., male paratype. 7. Anterior end of body; 8 . Middle body segment; 9. Posterior end of body; 10. First leg.; 11. Anterior gonopods, anterior view; 12. Right posterior gonopod, ectal view; 13. Right posterior gonopod, posterior view. 
SPELEOLOGY, I
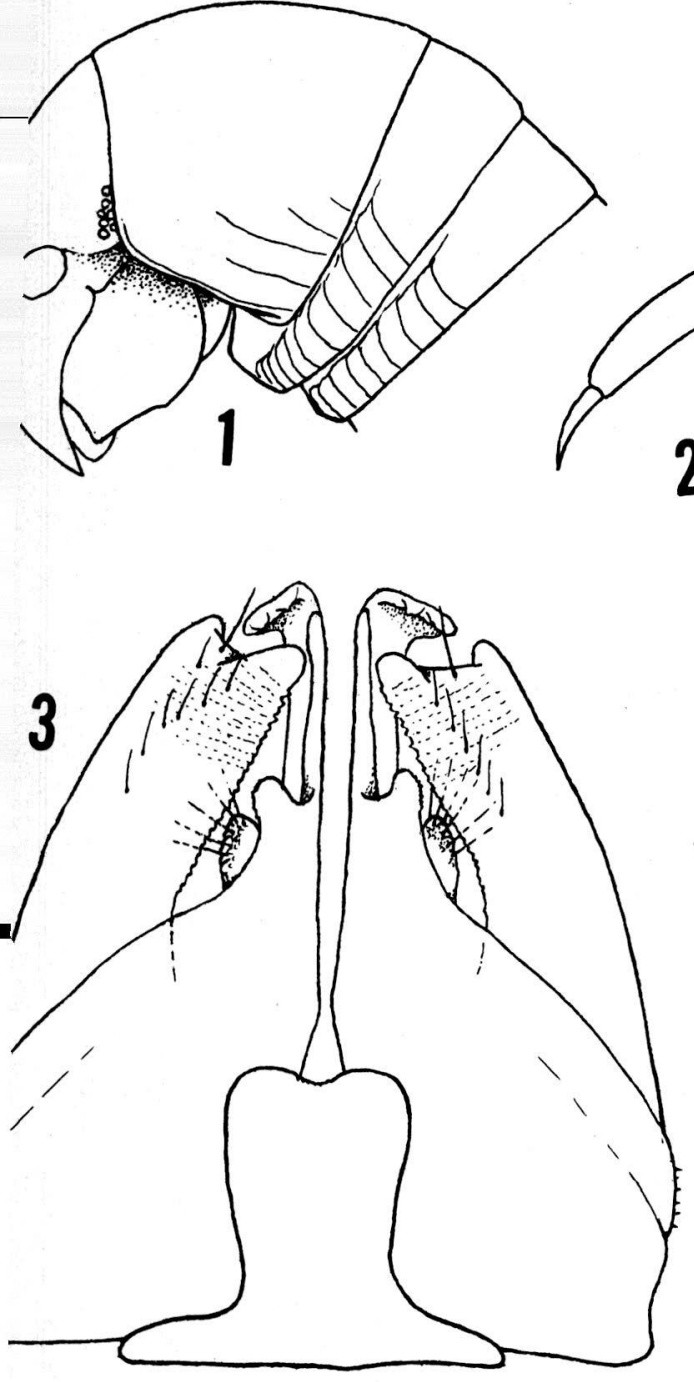

(Causey, 1)
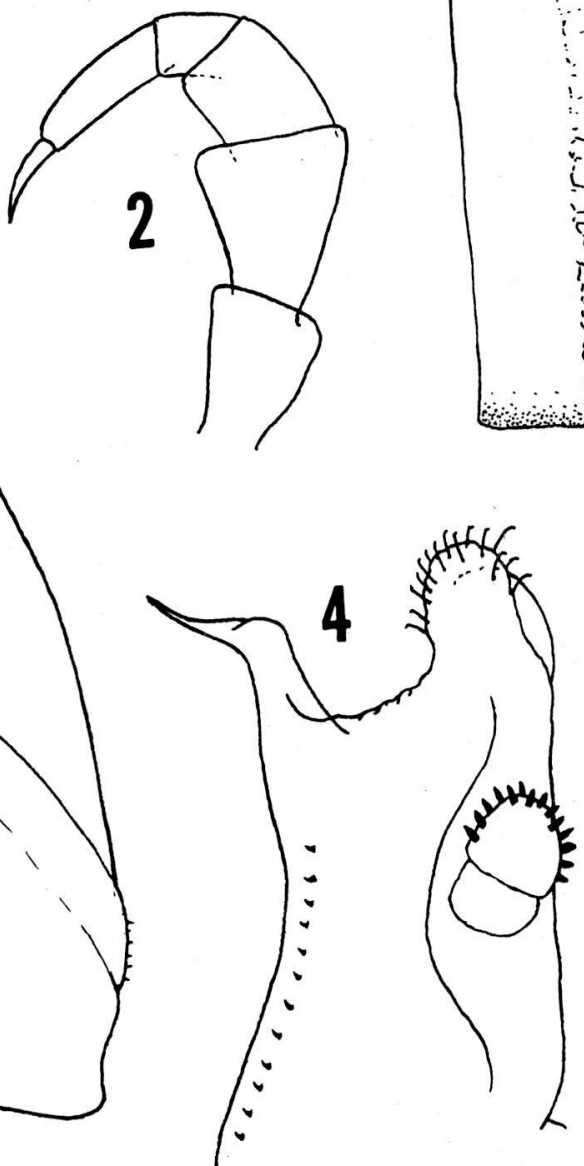

PLATE 58
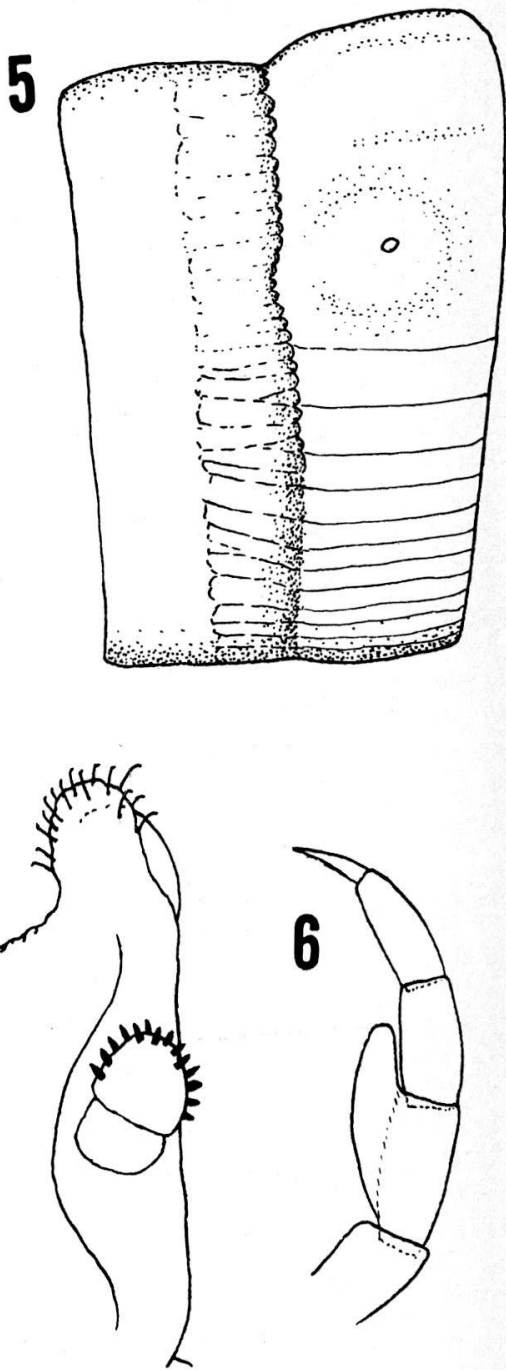

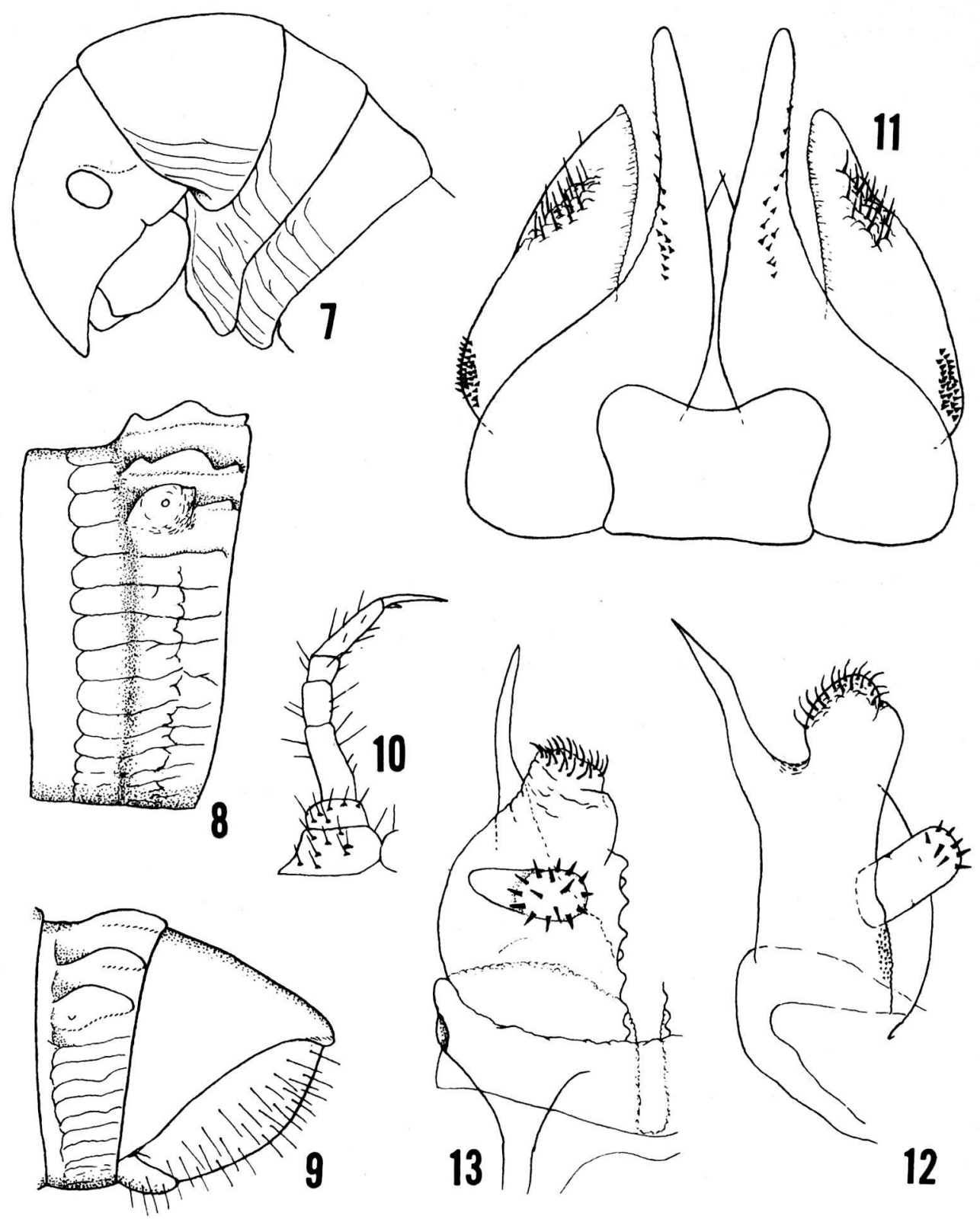